\title{
Solid Phase Synthesis of 3,4,5-Trisubstituted-1,2,4-Triazoles Derivatives from the Resin-Bound Acylhydrazines
}

\author{
Rongjian Xie, Xingang Liu, Chao Mai, Zhanxiang Liu* \\ Department of Chemistry, Zhejiang University (Xixi Campus), Hangzhou, China \\ Email: *liuzhanx@zju.edu.cn
}

Received January 18, 2013; revised March 9, 2013; accepted April 13, 2013

Copyright (C) 2013 Rongjian Xie et al. This is an open access article distributed under the Creative Commons Attribution License, which permits unrestricted use, distribution, and reproduction in any medium, provided the original work is properly cited.

\begin{abstract}
An extension of our methodology on solid-phase synthesis of 3,4,5-trisubstituted-1,2,4-triazoles under mild conditions has been developed. Firstly, the resin-bound acylhydrazine is reacted with orthoesters to provide resin-bound 1,3,4oxadiazoles. Secondly, condensation of 1,3,4-oxadiazoles resin with the corresponding arylamines hydrochloride to form the resin-bound triazoles. 3,4,5-Trisubstituted-1,2,4-triazoles derivatives were obtained from resin-bound acylhydrazines in several steps providing $78 \%-87 \%$ overall yields and excellent purity. The advantages of this method include straightforward operation and high yield and purity of the products.
\end{abstract}

Keywords: Resin-Bound Acylhydrazine; Solid-Phase Synthesis; 1,2,4-Triazoles

\section{Introduction}

Substituted 1,2,4-triazoles play an important role in organic chemistry due to their presence as key structural units in pharmaceuticals and biologically active heterocycles [1]. Compounds possessing the 1,2,4-triazole moiety have been reported to display antimicrobial activity [2], antifungal [3], antibacterial [4,5], anti-inflammatory [6] and antituberculosis [7] activities. They also can be used as peptidomimetic moieties and as hydrogen bond acceptors $[8,9]$ or as amide bond isostere for the design of receptor ligands in order to enhance their pharmacokinetic properties [10]. It is also well established that various derivatives of 1,2,4-triazole can be used for treating non-Hodgkin's lymphoma [11]. Moreover, multiply substituted 1,2,4-triazoles are an important common structural motifs with wide applications in coordination chemistry [12,13] and material chemistry [14-16]. 3,4,5-Trisubstituted 1,2,4-triazoles also act as intermediates in the synthesis of many drugs available in the market such as maraviroc (UK-427,857) [17], triazolam [18] and sitagliptin (MK-0431) [19].

In view of their great significance and useful applications, various synthetic methodologies of multiply substituted 1,2,4-triazole derivatives have been developed

\footnotetext{
"Corresponding author.
}

[20]. Generally 1,2,4-triazole derivatives are synthesized by the cyclodehydration of $\mathrm{N}$-acylamidrazones [21,22]. Several types of intermediates such as activated amide derivatives (chloromethylene amides, imidates, thioamides, thioimidates, and imidoylbenzotriazoles), amidrazones, N'-acetyl-N,N-dimethylhydrazonamides, oxadiazoles, N-nitrosoamidines, or arylphosphazoanilides can lead to $\mathrm{N}$-acylamidrazones [20]. For instance, a recently described method involves the use of N, N-dimethyl formamide dimethyl acetals, yielding triazoles in a one-pot reaction with good yields [23]. Johansson and coworkers have developed a method where triazoles can easily be prepared from a range of $\mathrm{N}$-substituted acetamides and hydrazides through the reaction with oxalylchloride [24]. The most commonly employed approach entails the direct condensation of thioamides with hydrazides [25], but this was not appealing because these starting materials are not commercially available in sufficient diversity. 1,2,4-Triazole derivatives were also synthesized directly from amidrazones and anhydrides using acetic acid or diethyl ether as a solvent [26,27].

One of the most important methods leading to the multiply substituted 1,2,4-triazole system involved the recyclization reactions of 1,3,4-oxadiazoles with primary amines because oxadiazoles are more stable precursors of $\mathrm{N}$-acylamidrazones than most of the activated amide de- 
rivatives. This methodology has been preferably adapted in recent years [28-33]. Very recently, protic ionic liquids as dual solvent-catalysts have been successfully used to promote reactions of organoamines with oxadiazoles to afford hindered 1,2,4-triazoles [34].

Many of the solution phase methodologies described above possess important drawbacks such as long reaction times, poor yields and exhaustive purification protocols. The large number of examples we found both in academic and patent literature convinced us that 1,2,4-triazoles core can be considered as a privileged substructure of choice for the design of new potentially bioactive compounds. In the process of drug development and/or lead structure optimization it is most welcome to use a method, which allows easy access to diverse compounds. Solid phase organic synthesis offers the opportunity for the development of novel methodologies for construction of libraries of small heterocyclic compounds [35-37]. In this regard, we have investigated the syntheses of various drug-like heterocycles on polystyrene supports in order to facilitate the automated parallel synthesis of discrete compound libraries. Nevertheless, there are only a few reports in the literature concerning solid phase synthesis for 1,2,4-triazoles [38-40]. So, a facile preparation 1,2,4triazoles for lead discovery is highly desirable. In this context we have foreseen that the use of new solid phase strategies to obtain 1,2,4-triazoles could overcome some of the deficiencies observed in previous synthetic protocols. We present a novel solid phase procedure that can be conducted in parallel form. In continuation of our particular interest in solid-phase synthesis of heterocycles from resin-bound acylhydride [41-45], herein, we describe new method for solid phase synthesis of 1,2,4-triazoles derivatives based on resin-bound acylhydrazines.

\section{Results and Discussions}

Scheme 1 shows the solid phase synthetic route of 1,2, 4-triazole derivatives. We have prepared resin-bound acylhydrazine 1 from the Merrifield resin according to our method previously reported [41]. The acylhydrazine resin 1 was reacted with excess orthoesters 2 catalyzed by alum [46] to give the corresponding resin-bound 1,3, 4-oxadiazoles 3 . After condensation of the corresponding aniline hydrochloride with resin 3 in pyridine, the resinbound triazoles 4 were obtained. The desired 1,2,4-triazole derivatives 5 were released at TFA/DCM cleavage for resin 4 in high yield and purity and characterized by the spectroscopic methods. The results are summarized in Table 1. The progress of the reaction was monitored by Fourier transform-infrared (FT-IR) spectroscopy. When the acylhydrazine resin 1 was reacted with orthoesters in the presence of Alum, the formation of resin-bound 1,3,4-oxadiazoles 3 was amenable to $\mathrm{KBr}$ FTIR monitoring (i.e., disappearance of the $\mathrm{C}=\mathrm{O}$ stretch at 1630 $\mathrm{cm}^{-1}$ and N-H stretch at $3429,3318 \mathrm{~cm}^{-1}$ and the appearance of a new $\mathrm{C}=\mathrm{N}$ stretch at $1590 \mathrm{~cm}^{-1}$ ). Resin 3 was then treated with various arylamines hydrochloride in pyridine to give the triazoles intermediate 4 which according to FTIR analysis shows a C-N stretch at 1515 $\mathrm{cm}^{-1}$. When the resin 4 was cleavaged by TFA/DCM, the product 5 was obtained in good yields and high purity.

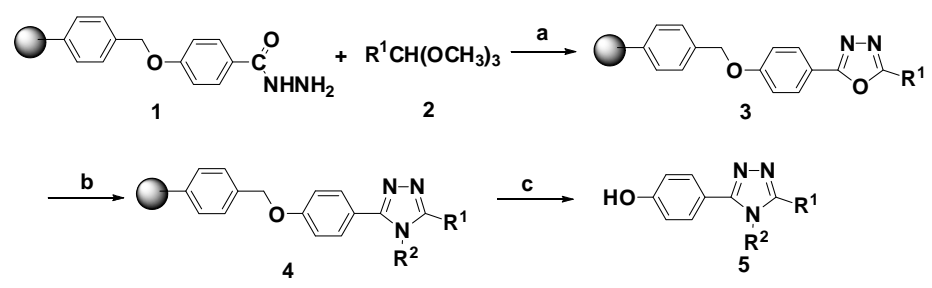

Scheme 1. Reagents and conditions (a) $\mathrm{KAl}\left(\mathrm{SO}_{4}\right)_{2} \cdot 12 \mathrm{H}_{2} \mathrm{O}(40 \mathrm{mmol} \%)$, reflux, $10 \mathrm{~h}$; (b) $\mathrm{R}^{2} \mathrm{NH}_{2} \cdot \mathrm{HCl}$, pyridine, reflux $12 \mathrm{~h}$; (c) TFA/CH $\mathrm{Cl}_{2}(1 / 4)$. r. t. 1 h.

Table 1. Solid-phase synthesis of 1,2,4-triazole derivatives.

\begin{tabular}{cccccc}
\hline Entry & Product & $\mathrm{R}^{1}$ & $\mathrm{R}^{2}$ & Yield $^{\mathrm{a}}$ (\%) & Purity $^{\mathrm{b}}$ (\%) \\
\hline 1 & $5 \mathbf{a}$ & $\mathrm{H}$ & $\mathrm{C}_{6} \mathrm{H}_{4} \mathrm{Me}-p$ & 85 & 91 \\
2 & $5 \mathbf{b}$ & $\mathrm{H}$ & $\mathrm{Ph}$ & 78 & 93 \\
3 & $5 \mathbf{c}$ & $\mathrm{CH}_{3}$ & $\mathrm{C}_{6} \mathrm{H}_{4} \mathrm{Me}-p$ & 86 & 92 \\
4 & $5 \mathbf{d}$ & $\mathrm{CH}_{3}$ & $\mathrm{Ph}$ & 84 & 95 \\
5 & $5 \mathbf{e}$ & $\mathrm{CH}_{3}$ & $\alpha-\mathrm{C}_{10} \mathrm{H}_{7}$ & 82 & 94 \\
6 & $5 \mathrm{f}$ & $\mathrm{CH}_{3} \mathrm{CH}_{2} \mathrm{CH}_{2}$ & $\mathrm{C}_{6} \mathrm{H}_{4} \mathrm{Me}-p$ & 87 & 98 \\
7 & $5 \mathbf{g}^{\mathbf{c}}$ & $\mathrm{CH}_{3} \mathrm{CH}_{2} \mathrm{CH}_{2}$ & $\mathrm{C}_{6} \mathrm{H}_{4} \mathrm{NO}_{2}-p$ & $/$ & $/$ \\
8 & $5 \mathrm{~h}^{\mathbf{c}}$ & $\mathrm{CH}_{3} \mathrm{CH}_{2} \mathrm{CH}_{2}$ & $\mathrm{C}_{6} \mathrm{H}_{4} \mathrm{CF}_{3}-p$ & $/$ & $/$ \\
\hline
\end{tabular}

${ }^{a}$ Yield of crude product based on the loading of acylhydrazine resin $1 ;{ }^{b}$ Determined by HPLC analysis (area \%); ${ }^{\mathrm{c}}$ The triazole product was not obtained, we got the 4-(5-propyl-1,3,4-oxadiazol-2-yl)phenol. 
To illustrate the versatility of this methodology, various commercially available orthoesters and amines analogues (Table 1) were used to prepare triazole resin 4. All the orthoesters used in reaction can offer the corresponding oxadiazole resin 3 . While for electron-rich aromatic amines, both the yield and purity of triazoles are good consisting with the electronic effects observed in traditional solution phase synthesis. But when the electron-poor arylamines were used, such as p-NO2 and p-CF3 substituted anilines, the corresponding triazoles were not obtained. After cleavage by TFA/DCM, we got the 4-(5-propyl-1,3,4-oxadiazol-2-yl)phenol which is the corresponding product cleavaged from oxadiazole resin 3 (Table 1, entries 7 and 8). Using this methodology, we have synthesized a representative set of 1,2,4-triazole-3thiones derivatives 5 (Table 1) in $76 \%$ - $89 \%$ overall yield, indicating an good yield for each step of the reaction.

In summary, we have developed a new strategy for the preparation of 3,4,5-trisubstituted 1,2,4-triazoles via solid phase synthesis. This process provided a useful method for the preparation of diverse 1,2,4-triazoles from readily accessible reactants under mild reaction conditions. The use of resin-bound acylhydrazines in the reaction benefits the solid-phase synthetic route because it not only provides a short synthetic route to the desired products but its chemical versatility also adds to the diversity of the library. The 1,2,4-triazoles derivatives were synthesized in several steps providing $76 \%-89 \%$ overall yields and excellent purity. The developed method can be applied to the preparation of libraries containing the triazole moiety for potential drug discovery. This synthetic methodology is because all the reactions were carried out under mild conditions. Further work is in progress on the solid-phase synthesis of heterocyclic compounds via the resin-bound acylhydrazines.

\section{Experimental}

Starting materials were obtained from commercial suppliers and used without further purification. Solvents were dried and distilled before use. Merrifield resin (100 - 200 mesh, cross-linked with 1\% divinylbenzene, loading $1.95 \mathrm{mmol} / \mathrm{g} \mathrm{Cl}$ ) was purchased from commercial sources (Nankai University).

Acylhydrazine resin 1 was prepared from the Merrifield resin according to our method previously reported [41]. ${ }^{1} \mathrm{H}$ NMR (400 MHz) and ${ }^{13} \mathrm{C}$ NMR (100 MHz) spectra were recorded on a Bruker Avance (400 MHz) spectrometer, using DMSO- $\mathrm{d}_{6}$ as the solvent and TMS as internal standard. Mass spectroscopy data of the products were collected on an HRMS-APCI instrument or a lowresolution MS instrument using EI or ESI ionization. IR spectra were recorded on a Bruck Vector 22 spectropho- tometer. High performance liquid chromatography (HPLC) was performed on an Agilent 1100 (column, Eclipse XDB$\mathrm{C} 185 \mu \mathrm{m}, 4.6 \times 150 \mathrm{~mm}$; mobile phase, $\mathrm{MeOH} / \mathrm{H}_{2} \mathrm{O}$, 80/20 (v/v); flow rate, $1.0 \mathrm{~mL} / \mathrm{min}$; detector, UV 254 $\mathrm{nm})$. The samples were further purified by thinlayer chromatography (TLC) for ${ }^{13} \mathrm{C}$ NMR.

\section{A General Procedure for Synthesis of 1,2,4-Triazoles}

To the mixture of the acylhydrazine resin $1(0.5 \mathrm{~g}$, loading $=1.59 \mathrm{mmol} / \mathrm{g}$, based on $\mathrm{N}$ microanalysis) in orthoester $(5 \mathrm{~mL})$, alum $\mathrm{KAl}\left(\mathrm{SO}_{4}\right)_{2} \cdot 12 \mathrm{H}_{2} \mathrm{O}(0.38 \mathrm{~g}, 0.8$ mmol) was added. Then the mixture was stirred and heated at $100^{\circ} \mathrm{C}$ for $10 \mathrm{~h}$. The resin was filtered and washed with $\mathrm{H}_{2} \mathrm{O}(5 \mathrm{~mL} \times 3)$, $($ EtOH $(5 \mathrm{~mL} \times 3)$ and $\mathrm{CH}_{2} \mathrm{Cl}_{2}(5 \mathrm{~mL} \times 3)$ to remove contaminated species and then dried to afford the resin 3.

A mixture of resin 3, aniline hydrochloride $(1.03 \mathrm{~g}, 8$ mmol), and pyridine $(5 \mathrm{~mL})$ was refluxed for $12 \mathrm{~h}$. Then it was filtered and the resin was washed with $10 \% \mathrm{HCl}(5$ $\mathrm{mL} \times 3), \mathrm{H}_{2} \mathrm{O}(10 \mathrm{~mL} \times 3), \mathrm{EtOH}(5 \mathrm{~mL} \times 3)$ and $\mathrm{CH}_{2} \mathrm{Cl}_{2}$ $(5 \mathrm{~mL} \times 3)$ and dried to affored the resin $4 \mathrm{~b}$.

The resin $\mathbf{4 b}$ was well swallen in $3 \mathrm{~mL} \mathrm{CH}_{2} \mathrm{Cl}_{2}$, then $0.5 \mathrm{~mL}$ TFA was added. The mixture was stirred at room temperature for $1 \mathrm{~h}$ and then filtered. The resin was washed completely with EtOH $(5 \mathrm{~mL} \times 3)$ and acetone $(5$ $\mathrm{mL} \times 3)$. The filtrate was combined to afford the crude product 5 by evaporation.

All compounds gave satisfactory $400 \mathrm{M}{ }^{1} \mathrm{H}$ NMR, IR, and HRMS spectra.

\section{4-(4-(p-tolyl)-4H-1,2,4-triazol-3-yl)phenol (5a)}

$\mathrm{mp} 280^{\circ} \mathrm{C}-281{ }^{\circ} \mathrm{C} ;{ }^{1} \mathrm{H}$ NMR $\delta=9.85(\mathrm{~s}, 1 \mathrm{H}), 8.71(\mathrm{~s}$, 1H), $7.31(\mathrm{~d}, J=7.2 \mathrm{~Hz}, 2 \mathrm{H}), 7.23(\mathrm{~m}, 4 \mathrm{H}), 6.74(\mathrm{~d}, J=$ $8.4 \mathrm{~Hz}, 2 \mathrm{H}), 2.36(\mathrm{~s}, 3 \mathrm{H}) .{ }^{13} \mathrm{C}$ NMR 159.0, 152.7, 145.5, $139.1,132.5,130.5,130.2,126.2,117.6,115.7,21.0$. IR 2603, 1610, 1513, 1446, 1276, 1247, 1181, 845, 813 $\mathrm{cm}^{-1}$. Calcd for $\mathrm{C}_{15} \mathrm{H}_{13} \mathrm{~N}_{3} \mathrm{O}, 251.1059$. Found: 251.1052

\section{4-(4-phenyl-4H-1,2,4-triazol-3-yl)phenol (5b)}

$\mathrm{mp} 241^{\circ} \mathrm{C}-243{ }^{\circ} \mathrm{C} ;{ }^{1} \mathrm{H}$ NMR $\delta=9.97(\mathrm{~s}, 1 \mathrm{H}), 8.81(\mathrm{~s}$, 1H), $7.51(\mathrm{~m}, 3 \mathrm{H}), 7.36(\mathrm{~m}, 2 \mathrm{H}), 7.19$ (d, $J=8.4 \mathrm{~Hz}, 2 \mathrm{H})$, $6.74(\mathrm{~d}, J=8.8 \mathrm{~Hz}, 2 \mathrm{H}) .{ }^{13} \mathrm{C}$ NMR $159.0,152.7,145.5$, 135.0, 130.3, 130.1, 129.5, 126.4, 117.3, 115.7. IR (KBr): 3094, 2591, 1612, 1506, 1438, 1388, 1281, 1243, 834, $769,691 \mathrm{~cm}^{-1}$; Calcd for $\mathrm{C}_{14} \mathrm{H}_{11} \mathrm{~N}_{3} \mathrm{O}, 237.0902$, Found: 237.0900

4-(5-methyl-4-phenyl-4H-1,2,4-triazol-3-yl)phenol (5c)

mp $282^{\circ} \mathrm{C}-283^{\circ} \mathrm{C} .{ }^{1} \mathrm{H}$ NMR $\delta=9.88(\mathrm{~s}, 1 \mathrm{H}), 7.53(\mathrm{~m}$, $3 \mathrm{H}), 7.38(\mathrm{~m}, 2 \mathrm{H}), 7.12(\mathrm{~m}, 2 \mathrm{H}), 6.68(\mathrm{~m}, 2 \mathrm{H}), 2.19(\mathrm{~s}$, 3H). ${ }^{13} \mathrm{C}$ NMR 158.8, 153.5, 152.0, 135.2, 130.3, 129.8, $129.7,127.9,118.2,115.6,11.3$. IR 2591, 1610, 1539, 1512, 1439, 1411, 1272, 1240, 845, cm ${ }^{-1}$; Calcd for $\mathrm{C}_{15} \mathrm{H}_{13} \mathrm{~N}_{3} \mathrm{O}, 251.1059$. Found: 251.1052. 


\section{(5d)}

4-(5-methyl-4-(p-tolyl)-4H-1,2,4-triazol-3-yl)phenol

$\mathrm{mp} 279^{\circ} \mathrm{C}-280^{\circ} \mathrm{C} ;{ }^{1} \mathrm{H}$ NMR $\delta=9.93(\mathrm{~s}, 1 \mathrm{H}), 7.33(\mathrm{~d}$, $J=8.0 \mathrm{~Hz}, 2 \mathrm{H}), 7.25(\mathrm{~d}, J=8.0 \mathrm{~Hz}, 2 \mathrm{H}), 7.15(\mathrm{~d}, J=8.0$ $\mathrm{Hz}, 2 \mathrm{H}), 6.70(\mathrm{~d}, J=8.0 \mathrm{~Hz}, 2 \mathrm{H}), 2.36(\mathrm{~s}, 3 \mathrm{H}), 2.18$ (s, 3H). ${ }^{13} \mathrm{C}$ NMR; $158.8,153.5,152.1,139.5,132.5$, $130.8,130.0,128.6,127.6,118.1,115.6,21.1,11.2$. IR $3321,3147,2943,2589,1533,1499,1442,1286,1243$, $835,690 \mathrm{~cm}^{-1}$. Calcd for $\mathrm{C}_{16} \mathrm{H}_{15} \mathrm{~N}_{3} \mathrm{O}: 265.1215$. Found: 265.1211 .

4-(5-methyl-4-(naphthalen-1-yl)-4H-1,2,4-triazol-3yl)phenol (5e)

$\mathrm{mp} 254^{\circ} \mathrm{C}-256^{\circ} \mathrm{C} .{ }^{1} \mathrm{H}$ NMR $\delta=9.76(\mathrm{~s}, 1 \mathrm{H}), 8.17(\mathrm{~d}$, $J=8 \mathrm{~Hz}, 1 \mathrm{H}), 8.10(\mathrm{~d}, J=8 \mathrm{~Hz}, 1 \mathrm{H}), 7.74(\mathrm{~m}, 1 \mathrm{H}), 7.70$ (m, 1H), $7.62(\mathrm{~m}, 1 \mathrm{H}), 7.54(\mathrm{~m}, 1 \mathrm{H}), 7.09(\mathrm{~m}, 3 \mathrm{H}), 6.56$ (d, $J=8.4 \mathrm{~Hz}, 2 \mathrm{H}), 2.05$ (s, 3H). ${ }^{13} \mathrm{C}$ NMR 158.7, 154.1, $152.7,134.1,131.2,130.7,129.6,129.0,128.7,127.5$, $127.2,126.3,121.5,118.3,115.6,115.5,10.8$. IR $(\mathrm{KBr}$, $\mathrm{cm}^{-1}$ ): 3146, 2925, 2618, 1582, 1513, 1437, 1290, 1239, 1173, 838, 702. Calcd for $\mathrm{C}_{19} \mathrm{H}_{15} \mathrm{~N}_{3} \mathrm{O}, 301.1215$. Found: 301.1216 . (5f)

4-(5-propyl-4-(p-tolyl)-4H-1,2,4-triazol-3-yl)phenol

$\mathrm{mp} 234^{\circ} \mathrm{C}-235^{\circ} \mathrm{C} ;{ }^{1} \mathrm{H}$ NMR (400 MHz DMSO-d $\left.\mathrm{d}_{6}\right): \delta$ $=9.83(\mathrm{~s}, 1 \mathrm{H}), 7.33(\mathrm{~d}, J=8 \mathrm{~Hz}, 2 \mathrm{H}), 7.24(\mathrm{~d}, J=8 \mathrm{~Hz}$, $2 \mathrm{H}), 7.14(\mathrm{~d}, J=8.4 \mathrm{~Hz}, 2 \mathrm{H}) .6 .67(\mathrm{~d}, J=8.4 \mathrm{~Hz}, 2 \mathrm{H})$, $2.48(\mathrm{t}, J=7.6 \mathrm{~Hz}, 2 \mathrm{H}), 2.37$ (s, 3H), $1.55(\mathrm{~m}, 2 \mathrm{H}), 0.84$ $(\mathrm{t}, J=7.4 \mathrm{~Hz}, 3 \mathrm{H}) .{ }^{13} \mathrm{CNMR} \delta=158.8,155.1,153.5$, $139.5,132.5,130.7,129.8,127.8,118.2,115.6,26.9$, 21.1, 20.3, 14.0. IR 3423,2968, 1514, 1467, 1282, 828 $\mathrm{cm}^{-1}$; Calcd for $\mathrm{C}_{18} \mathrm{H}_{19} \mathrm{~N}_{3} \mathrm{O}$, 293.1528. Found: 293.1530.

4-(5-propyl- 1,3,4- oxadiazol-2-yl)phenol (5g, 5h)

$\mathrm{mp} 152^{\circ} \mathrm{C} \sim 153^{\circ} \mathrm{C} .{ }^{1} \mathrm{H}$ NMR $\delta=10.27(\mathrm{~s}, 1 \mathrm{H}), 7.79(\mathrm{~d}$, $J=8.8 \mathrm{~Hz}, 2 \mathrm{H}), 6.93(\mathrm{~d}, J=8.8 \mathrm{~Hz}, 2 \mathrm{H}), 2.84(\mathrm{t}, J=7.6$ $\mathrm{Hz}, 2 \mathrm{H}), 1.75(\mathrm{~m}, 2 \mathrm{H}), 0.95(\mathrm{t}, J=7.6 \mathrm{~Hz}, 3 \mathrm{H}) .{ }^{13} \mathrm{C} \mathrm{NMR}$ $\delta=166.2,164.3,160.9,128.6,116.5,114.7,26.7,19.8$, 13.7 IR 3426,2971, 1580, 1505, 1435, 1282, 1236, 1172, 844, 741, $698 \mathrm{~cm}^{-1}$; Calcd for $\mathrm{C}_{11} \mathrm{H}_{12} \mathrm{~N}_{2} \mathrm{O}_{2}, 204.0899$. Found: 204.0898 .

\section{Acknowledgements}

The authors are grateful for the financial support from the National Natural Science Foundation of China No. 20802068 and Natural Science Foundation of Zhejiang province No. Y4110100.

\section{REFERENCES}

[1] A. Curtis and N. Jennings, "1,2,4-Triazoles," In: A. R. Katritzky, C. A. Ramsden, E. F. V. Scriven and R. J. K. Taylor, Eds., Comprehensive Heterocyclic Chemistry III, Vol. 5, Elsevier Ltd., New York, 2008, pp. 159-209.

[2] K. D. Patel, B. D. Mistry and K. R. Desai, "Synthesis and Antimicrobial Activity of 1,2,4-Triazoles," Journal of In- dian Chemical Society, Vol. 79, No. 9, 2002, pp. 964-965.

[3] K. Shalini, N. Kumar, S. Drabu and P. K. Sharma, "Advances in Synthetic Approach to and Antifungal Activity of Triazoles," Beilstein Journal of Organic Chemistry, Vol. 7, 2011, pp. 668-677. doi:10.3762/bjoc.7.79

[4] K. Colanceska-Ragenovic, V. Dimova, V. Kakurinov, D. G. Molnar and A. Buzarovska, "Synthesis, Antibacterial and Antifungal Activity of 4-Substituted-5-Aryl-1,2,4Triazoles," Molecules, Vol. 6, No. 10, 2001, pp. 815-824. doi:10.3390/61000815

[5] B. S. Holla, K. N. Poorjary, B. S. Rao and M. K. Shivananda, "New Bis-Aminomercaptotriazoles and BisTriazolothia-Diazoles as Possible Anticancer Agents," European Journal of Medicinal Chemistry, Vol. 37, No. 6, 2002, pp. 511-517. doi:10.1016/S0223-5234(02)01358-2

[6] G. Turan-Zitouni, Z. A. Kaplancikli, A. Özdemir, P. Chevallet, H. B. Kandilci and B. Gümüsel, "Studies on 1,2, 4-Triazole Derivatives as Potential Anti-Inflammatory Agents," Archiv der Pharmazie, Vol. 340, No. 11, 2007, pp. 586-590. doi:10.1002/ardp.200700134

[7] G. R. Jadhav, M. U. Shaikh, R. P. Kale, M. R. Shiradkar and C. H. Gill, "SAR Study of Clubbed $[1,2,4]$-Triazolyl with Fluorobenzimidazoles as Antimicrobial and Antituberculosis Agents," European Journal of Medicinal Chemistry, Vol. 44, No. 7, 2009, pp. 2930-2935. doi:10.1016/j.ejmech.2008.12.001

[8] S. Borg, G. Estenne-Bouhtou, K. Luthman, I. Csöregh, W. Hesselink and U. Hacksell, "Synthesis of 1,2,4-Oxadiazole-1,3,4-Oxadiazole- and 1,2,4-Triazole-Derived Dipeptidomimetics," The Journal of Organic Chemistry Vol. 60, No. 10, 1995, pp. 3112-3120. doi:10.1021/ jo00115a029

[9] C. Chen, R. Dagnino, C. Q. Huang, J. R. McCarthy and D. E. Grigoriadis, "1-Alkyl-3-Amino-5-Aryl-1H-[1,2,4]Triazoles: Novel Synthesis via Cyclization of N-Acyl-S-Methylisothioureas with Alkylhydrazines and Their Potent Corticotropin-Releasing Factor-1 (CRF1) Receptor Antagonist Activities," Bioorganic \& Medicinal Chemistry Letters, Vol. 11, No. 24, 2001, pp. 3165-3168. doi:10.1016/S0960-894X(01)00657-6

[10] S. K. Thompson, A. M. Eppley, J. S. Frazee, M. G. Darcy, R. T. Lum, T. A Tomaszek, L. A. Ivanoff, J. F. Morris, E. J. Sternberg, D. M. Lambert, A. V. Fernandez, S. R. J. Petteway, T. D. Meek, B. W. Metcalf and J. G. Gleason, "Synthesis and Antiviral Activity of a Novel Class of HIV-1 Protease Inhibitors Containing a Heterocyclic P1'P2' Amide Bond Isostere," Bioorganic \& Medicinal Chemistry Letters, Vol. 4, No. 20, 1994, pp. 2441-2446. doi:10.1016/S0960-894X(01)80406-6

[11] F. Kevin, "Triazole Derivatives and Their Preparation and Method for Treating Non-Hodgkin's Lymphoma," US Patent No. 2006-808341, 2007.

[12] M. H. Klingele and S. Brooker, "The Coordination Chemistry of 4-Substituted 3,5-Di(2-Pyridyl)-4H-1,2,4-Triazoles and Related Ligands," Coordination Chemistry Reviews, Vol. 241, No. 1-2, 2003, pp. 119-132. doi:10.1016/S0010-8545(03)00049-3

[13] G. Aromí, L. A. Barrios, O. Roubeau and P. Gamez, "Triazoles and Tetrazoles: Prime Ligands to Generate Remarkable Coordination Materials," Coordination Chem- 
istry Reviews, Vol. 255, No. 5-6, 2011, pp. 485-546. doi:10.1016/j.ccr.2010.10.038

[14] X. W. Chen, C. Y. Liu, T. H. Jen, S. A. Chen and S. Holdcroft, "Synthesis and Characterization of a Fullerene Bearing a Triazole Group," Chemistry of Materials, Vol. 19, No. 20, 2007, pp. 5194-5199. doi: $10.1021 / \mathrm{cm} 071686 \mathrm{y}$

[15] Z. Y. Zhou, X. W. Chen and S. Holdcroft, "Stabilizing Bicontinuous Nanophase Segregation in $\pi \mathrm{CP}-\mathrm{C}_{60}$ DonorAcceptor Blends," Journal of the American Chemical Society, Vol. 130, No. 35, 2008, pp. 11711-11718. doi:10.1021/ja802021z

[16] P. L. Wu, X. J. Feng, H. L. Tam and K. W. Cheah, "Efficient Three-Photon Excited Deep Blue Photoluminescence and Lasing of Diphenylamino and 1,2,4-Triazole Endcapped Oligofluorenes," Journal of the American Chemical Society, Vol. 131, No. 3, 2009, pp. 886-887. doi:10.1021/ja806703v

[17] S. J. Haycock-Lewandowski, N. J. Mawby, A. Wilder and J. Ahman, "Development of a Bulk Enabling Route to Maraviroc (UK-427,857), a CCR-5 Receptor Antagonist," Organic Process Research \& Development, Vol. 12, No. 6, 2008, pp. 1094-1103. doi:10.1021/op8000614

[18] S. Fustero, J. Gonzalez and C. Del Pozo, “1,4-Benzodiazepine N-Nitrosoamidines: Useful Intermediates in the Synthesis of Tricyclic Benzodiazepines," Molecules, Vol. 11 , No. 8, 2006, pp. 583-588. doi: $10.3390 / 11080583$

[19] K. B. Hansen, J. Balsells, S. Dreher, Y. Hsiao, M. Kubryk, M. Palucki, N. Rivera, D. Steinhuebel, J. D. Armstrong III, D. Askin and E. J. Grabowski, "First Generation Process for the Preparation of the DPP-IV Inhibitor Sitagliptin," Organic Process Research \& Development, Vol. 9, No. 5, 2005, pp. 634-639. doi:10.1021/op0500786

[20] A. Moulin, M. Bibian, A. L. Blayo, S. E. Habnouni, J. Martinez and J. A. Fehrentz, "Synthesis of 3,4,5-Trisubstituted-1,2,4-Triazoles," Chemical Reviews, Vol. 110, No. 4, 2010, pp. 1809-1827. doi:10.1021/cr900107r

[21] N. I. Korotkikh, A. V. Kiselev, A. V. Knishevitsky, G. F. Raenko, T. M. Pekhtereva and O. P. Shvaika, "Recyclization of 1, 3, 4-Oxadiazoles and Bis-1,3,4-Oxadiazoles into 1,2,4-Triazole Derivatives. Synthesis of 5-Unsubstituted 1,2,4-Triazoles," Chemistry of Heterocyclic Compounds, Vol. 41, No. 7, 2005, pp. 866-871. doi:10.1007/s10593-005-0240-2

[22] N. A. Meanwell, J. L. Romine, M. J. Rosenfeld, S. W. Martin, A. K. Trehan, J. J. K. Wright, M. F. Malley, J. Z. Gougoutas, C. L. Brassard, J. O. Buchanan, M. E. Federic, J. S. Fleming, M. Gamberdella, K. S. Hartl, G. B. Zavoico and S. M. Seiler, "Nonprostanoid Prostacyclin Mimetics 5. Structure-Activity-Relationships Associated with [3-[4(4,5-Diphenyl-2-Oxazolyl)-5-Oxazolyl] Phenoxy] Acetic Acid," Journal of Medicinal Chemistry, Vol. 36, No. 24, 1993, pp. 3884-3903. doi:10.1021/jm00076a018

[23] M. J. Stocks, D. R. Cheshire and R. Reynolds, "Efficient and Regiospecific One-Pot Synthesis of Substituted 1,2, 4-Triazoles," Organic Letters, Vol. 6, No. 17, 2004, pp. 2969-2971. doi:10.1021/o1048863a

[24] J. Lindström and M. H. Johansson, "Synthesis of 3-Aryl-
5-Methyl 4-Substituted [1,2,4] Triazoles," Synthetic Communications, Vol. 36, No. 15, 2006, pp. 2217-2229. doi:10.1080/00397910600638994

[25] A. J. Duplantier, E. L. Bachert, J. B. Cheng, V. L. Cohan, T. H. Jenkinson, K. G. Kraus, M. W. McKechney, J. D. Pillar and J. W. Watson, "SAR of a Series of 5,6-Dihydro-(9H)-Pyrazolo [3,4-c]-1,2,4-Triazolo[4,3-Alpha]Pyridines as Potent Inhibitors of Human Eosinophil Phosphodiesterase," Journal of Medicinal Chemistry, Vol. 50, No. 2, 2007, pp. 344-349. doi:10.1021/jm060904g

[26] B. Modzelewska-Banachiewicz, J. Banachiewicz, A. Chodkowska, E. Jagiello-Wojtowicz and L. Mazur, "Synthesis and Biological Activity of New Derivatives of 3-(3,4-Diaryl-1,2,4-Triazole-5-yl)Propenoic Acid," European Journal of Medicinal Chemistry, Vol. 39, No. 10, 2004, pp. 873-877. doi:10.1016/j.ejmech.2004.07.002

[27] B. Modzelewska-Banachiewicz, M. Ucherek, M. Zimecki, J. Kutkowska, T. Kaminska, B. Morak-Mlodawska, R. Paprocka, M. Szulc, G. Lewandowski, J. Marciniak and T. Bobkiewicz-Kozlowska, "Reactions of $\mathrm{N}^{3}$-Substituted Amidrazones with Cis-1,2-Cyclohexane Dicarboxylic Anhydride and Biological Activitiesof the Products," Archiv der Pharmazie, Vol. 345, No. 6, 2012, pp. 486-494. doi:10.1002/ardp.201100333

[28] S. Olson, S. D. Aster, K. Brown, L. Carbin, D. W. Graham, A. Hermanowski-Vosatka, C. B. LeGrand, S. S. Mundt, M. A. Robbins, J. M. Schaeffer, L. H. Slossberg, M. J. Szymonifka, R. Thieringer, S. D. Wright and J. M. Balkovec, "Adamantyl Triazoles as Selective Inhibitors of 11 Beta-Hydroxysteroid Dehydrogenase Type 1," Bioorganic \& Medicinal Chemistry Letters, Vol. 15, No. 19, 2005, pp. 4359-4362. doi:10.1016/j.bmcl.2005.06.040

[29] M. A. García, S. Martín-Santamaría, M. Cacho, F. M. Llave, M. Julian, A. Martínez, B. Pascual-Teresa and A. Ramos, "Synthesis, Biological Evaluation, and ThreeDimensional Quantitative Structure-Activity Relationship Study of Small-Molecule Positive Modulators of Adrenomedullin," Journal of Medicinal Chemistry, Vol. 48, No. 12, 2005, pp. 4068-4075. doi:10.1021/jm050021+

[30] M. Saitoh, J. Kunitomo, E. Kimura, H. Iwashita, Y. Uno, T. Onishi, N. Uchiyama, T. Kawamoto, T. Tanaka, C. D. Mol, D. R. Dougan, G. P. Textor, G. P. Snell, M. Takizawa, F. Itoh and M. Kori, "2-\{3-[4-(Alkylsulfinyl)Phenyl]1-Benzofuran-5-yl\}-5-Methyl-1,3,4-Oxadiazole Derivatives as Novel Inhibitors of Glycogen Synthase Kinase-3 Beta with Good Brain Permeability," Journal of Medicinal Chemistry, Vol. 52, No. 20, 2009, pp. 6270-6286. doi:10.1021/jm900647e

[31] A. Brown, D. Ellis, D. Pearce, M. Ralph and N. Sciammetta, "Aryloxypyrazines as Highly Selective Antagonists of Oxytocin," Bioorganic \& Medicinal Chemistry Letters, Vol. 19, No. 10, 2009, pp. 2634-2636. doi:10.1016/j.bmcl.2009.03.160

[32] T. Sugane, T. Tobe, W. Hamaguchi, I. Shimada, K. Maeno, J. Miyata, T. Suzuki, T. Kimizuka, A. Kohara, T. Morita, H. Doihara, K. Saita, M. Aota, M. Furutani, Y. Shimada, N. Hamada, S. Sakamoto and S. Tsukamoto, "Synthesis and Biological Evaluation of 3-Biphenyl-4-yl4-Phenyl-4H-1,2,4-Triazoles as Novel Glycine Transporter 1 Inhibitors," Journal of Medicinal Chemistry, Vol. 
54, No. 1, 2011, pp. 387-391. doi:10.1021/jm101031u

[33] P. H. J. Carlsen and K. B. Jørgensen, "Synthesis of Unsymmetrically Substituted 4H-1,2,4-Triazoles," Journal of Heterocyclic Chemistry, Vol. 31, 1994, pp. 805-807.

[34] X. F. Chen, R. Liu, Y. Xu and G. Zou, "Tunable Protic Ionic Liquids as Solvent-Catalysts for Improved Synthesis of Multiply Substituted 1,2,4-Triazoles from Oxadiazoles and Organoamines," Tetrahedron, Vol. 68, 2012, pp. 4813-4819. doi:10.1016/j.tet.2012.03.114

[35] P. Seneci, "Solid Phase Synthesis and Combinatorial chemistry," Wiley InterscienceJohn, Wiley \& Sons, New York, 2000.

[36] R. E. Dolle, "Comprehensive Survey of Combinatorial Library Synthesis," Journal Combintorial Chemistry, Vol. 6, No. 5, 2004, pp. 623-679. doi:10.1021/cc0499082

[37] P. H. Toy and Y. Lam, "Solid-Phase Organic Synthesis Concepts, Strategies, and Applications," John Wiley \& Sons, Inc., Hoboken, 2012.

[38] A. R. Katritzky, M. Qi, D. Feng, G. Zhang, M. C. Griffith and K. Watson, "Synthesis of 1,2,4-Triazole-Functionalized Solid Support and Its Use in the Solid-Phase Synthesis of Trisubstituted 1,2,4-1,2,4-Triazoles," Organic Letters, Vol. 1, No. 8, 1999, pp. 1189-1191. doi:10.1021/o1990186a

[39] S. D. Larsen and B. A. DiPaolo, "Traceless Solid-Phase Synthesis of 1,2,4-Triazoles Using a Novel Amine Resin," Organic Letters, Vol. 3, No. 21, 2001, pp. 3341-3344. doi:10.1021/o1016578a

[40] Y. G. Wang, W. M. Xu and X. Huang, "Selenium-Based SafetyCatch Linker: Solid-Phase Synthesis of Vinyl-Substituted Oxadiazoles and Triazoles," Journal of Combinatorial Chemistry, Vol. 9, No. 3, 2007, pp. 513-519. doi:10.1021/cc0700187

[41] Z. X. Liu, J. L. Zhao and X. Huang, "Solid-Phase Synthesis of 1,3,4-Oxadiazoline-5-Thione Derivatives from Resin Bound Acylhydrazines," Bioorganic \& Medicinal Chemistry Letters, Vol. 16, No. 7, 2006, pp. 1828-1830. doi:10.1016/j.bmcl.2006.01.002

[42] Z. X. Liu, Y. Y. Mu, J. Lin and Y. Y. Chen, "Traceless Solid-Phase Synthesis of 1, 2, 3-Thiadiazole Derivatives from Resin-Bound Acylhydrazine," Synthetic Communications, Vol. 38, No. 24, 2008, pp. 4407-4414. doi:10.1080/00397910802369521

[43] Z. X. Liu, Y. Y. Mu and Z. S. Song, "Solid Phase Synthesis of 4,5-Disubstituted 1, 2, 4-Triazol-3-One Derivatives from Resin-Bound Acylhydrazines," Journal of Chemical Research, No. 4, 2008, pp. 216-217.

[44] Z. X. Liu, Z. S. Song, J. L. Zhao and J. Y. Zheng, "SolidPhase Synthesis of 2-Arylamino-5-(4-Hydroxyphenyl)-1, 3,4-Thiadiazole Derivatives Based on Resin-Bound Acylhydrazines," Phosphorus, Sulfur and Silicon and the Related Elements, Vol. 185, No. 11, 2010, pp. 2375-2381. doi:10.1080/10426501003664176

[45] Z. X. Liu, Y. R. Yi, J. L. Zhao and M. X. Tang, "SolidPhase Synthesis of 4,5-Disubstituted-1,2,4-Triazole-3-Thione Derivatives Based on the Resin-Bound Acylhydrazines," Synthetic Communications, Vol. 42, No. 1, 2012, pp. 5561. doi:10.1080/00397911.2010.521609

[46] M. Dabiri, P. Salehi, M. Baghbanzadeh and M. Bahramnejad, "Alum $\left(\mathrm{KAl}\left(\mathrm{SO}_{4}\right)_{2} \cdot 12 \mathrm{H}_{2} \mathrm{O}\right)$ : An Efficient and Inexpensive Catalyst for the One-Pot Synthesis of 1,3,4Oxadiazoles under Solvent-Free Conditions," Monatshefte für Chemie-Chemical Monthly, Vol. 138, No. 12, 2007, pp. 1253-1255. doi:10.1007/s00706-007-0724-0 